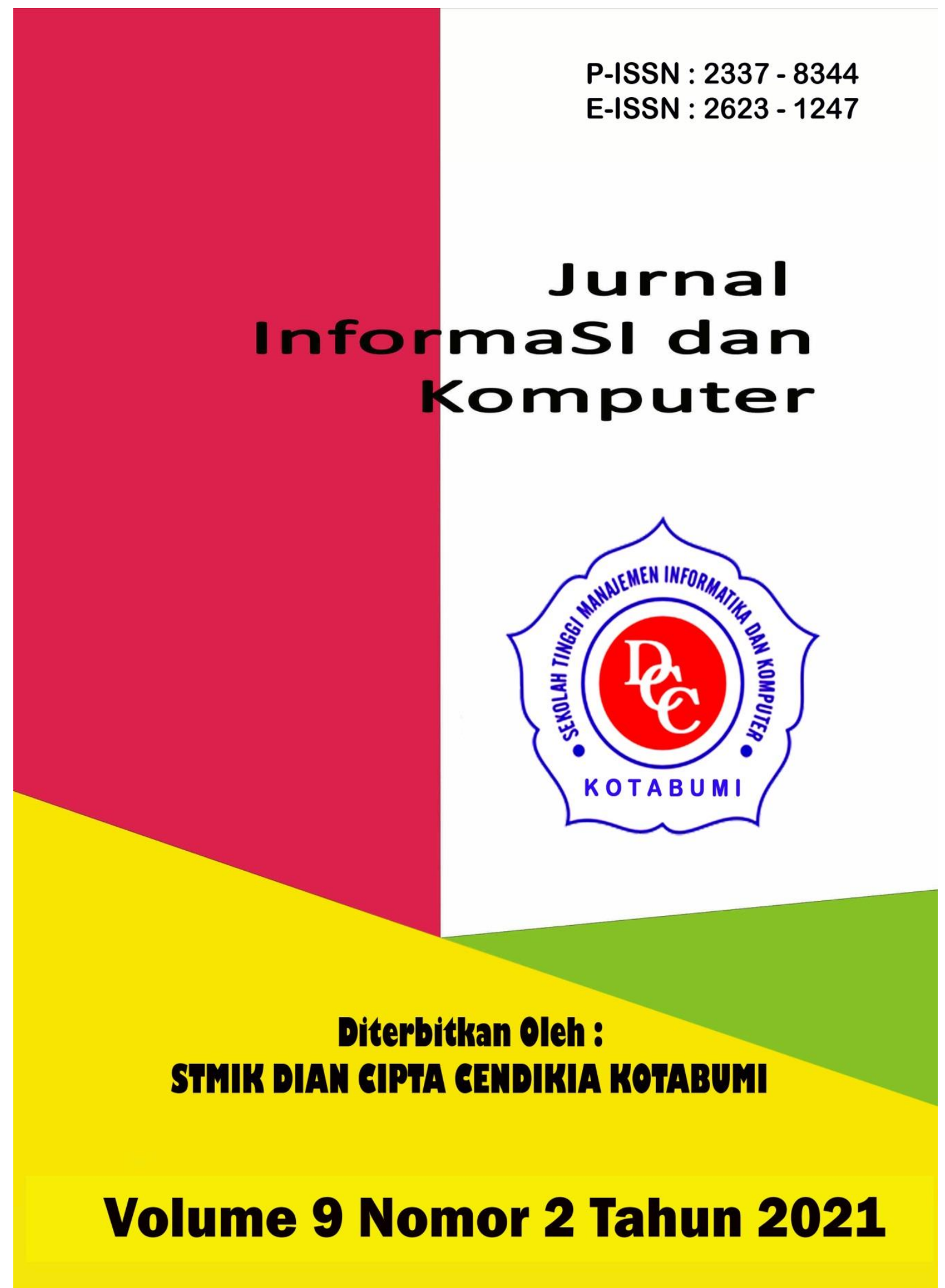




\section{Penerbit}

\section{Lembaga Penelitian STMIK Dian Cipta Cendikia Kotabumi}

Hak atas naskahh/tulisan tetap berada pada penulis, isi diluar tangung jawab penerbit dan Dewan Penyunting

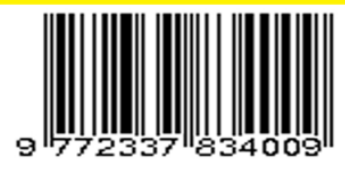




\section{PENGANTAR REDAKSI}

Puji syukur dipanjatkan kehadirat Tuhan Yang Maha Esa, atas karunia dan limpahan rahmatNYA jualah Jurnal Informasi dan komputer (JIK) STMIK Dian Cipta Cendikia Kotabumi ini dapat terwujud.Jurnal Informasi dan Komputer (JIK) yang terbit dua (2) kali dalam setahun ini merupakan suatu wadah untuk penyebar luasan hasil-hasil penelitian, studi pustaka, karya ilmiah yang berkaitan dengan Informasi dan Komputer khususnya bagi dosen-dosen STMIK Dian Cipta Cendikia Kotabumi serta umumnya para cendikiawan, praktisi, peneliti ilmu Informatika dan Komputer.

Harapan, dengan diterbitkannya Jurnal Informasi dan Komputer (JIK) ini sebagai salah satu bentuk sumbangan pemikiran dalam pengembangan ilmu informatika dan komputer yang berkaitan dengan kajian-kajian di bidang tekhnologi Informatik, Komunikasi Data dan Jaringan Komputer, perancangan dan Rekayasa Perangkat Lunak, serta ilmu-ilmu yang terkait dengan bidang Informasi dan Komputer lainnya.

Berkenaan dengan harapan tersebut, kepada para peneliti, dosen dan praktisi yang memiliki hasil-hasil penelitian, kajian pustaka, karya ilmiah dalam bidang tersebut diatas, dengan bangga redaksi Jurnal Informasi dan Komputer (JIK) menerima naskah ringkasan untuk dimuat pada jurnal Informasi dan Komputer (JIK) STMIK Dian Cipta Cendikia Kotabumi dengan berpedoman pada penulisan naskah jurnal sebagaimana dilampirkan pada halaman belakang (Bagian kulit dalam) buku jurnal ini.

Mutu dari suatu jurnal ilmiah tidak hanya ditentukan oleh para pengelolanya saja, tetapi para penulis dan pembaca jualah yang mempunyai peranan besar dalam meningkatkan mutu jurnal Informatika dan Komputer ini. Merujuk pada realita ini kamu sangat mengharapkan peran aktif dari peneliti untuk bersama-sama menjaga dan memelihara keberlangsungan dari jurnal Informasi dan Komputer STMIK Dian Cipta Cendikia Kotabumi ini. Yang juga tidak kalah pentingnya dari partisipasi tersebut diatas, adalah saran dan kritik yang membangun dari pembaca yang budiman agar kiranya dapat disampaikan langsung kepada redaksi JIK. Saran dan kritik yang membangun akan dijadikan masukan dan pertimbangan yang sangat berarti guna peningkatan mutu dan kualitas Jurnal Informasi dan Komputer STMIK Dian Cipta Cendikia Kotabumi.

Tak lupa diucapkan terima kasih yang tak terhingga atas perhatian dan kerjasama dari semua pihak yang tak dapat disebutkan satu persatu hingga dapat diterbitkan nya Jurnal Informasi dan Komputer (JIK) STMIK Dian Cipta Cendikia Kotabumi. Semoga apa yang telah diperbuat untuk kebaikan akan menjadi amal ibadah, amin.

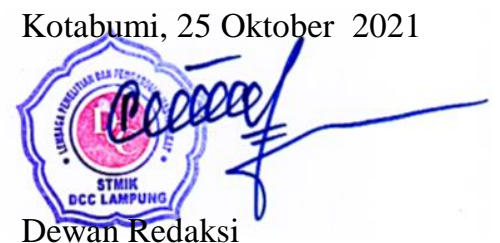




\section{JURNAL INFORMASI DAN KOMPUTER}

Volume 9 Nomor 2 Oktober 2021

Jurnal Informasi dan Komputer merupakan Sarana informasi ilmu pengetahuan, Tekhnologi dan Komunikasi yang berupa hasil penelitian, tulisan ilmiah, Ataupun studi pustaka. Jurnal ini terbit dua kali setahun pada bulan April dan Oktober. Berisi hasil penelitian ilmiah di bidang informatika yang bertujuan untuk menghubungkan adanya kesenjangan antar kemajuan teknologi dan hasil penelitian. Jurnal ini di terbitkan pertama kali pada tahun 2013.

Penanggung Jawab:

Ketua STMIK Dian Cipta Cendikia Kotabumi

\section{Pembina:}

Ketua STMIK Dian Cipta Cendikia Kotabumi Ketua Lembaga Penelitian STMIK Dian Cipta Cendikia Kotabumi

\section{Pimpinan Redaksi}

Dwi Marisa Efendi,.S.Kom.,M.Ti

\section{Redaksi pelaksana}

Rustam,.S.Kom,.M.Ti (STMIK Dian Cipta Cendikia Kotabumi)

Nurmayanti M.Kom (STMIK Dian Cipta Cendikia Kotabumi)

Sukatmi,.S.Kom., M.Kom (AMIK DCC Bandar Lampung)

Sampurna Dadi Riskiono,M.Kom (Universitas Teknokrat Indonesia)

Ifo Wahyu Pratama,S.Kom.,M.Ti(AMIK MASTER Lampung)

\section{Mitra Bestari}

Dr. RZ. ABDUL AZIZ, ST., MT (Institut Informatika dan Bisnis Darmajaya)

Dr. Dadang Sudrajat, S.Si, M.Kom (STMIK IKMI Cirebon)

Dr. Septafiansyah Dwi Putra, S.T., M.T (Politeknik Negeri Lampung)

Dr. Evi Grativiani, S.E., M.S.I (Universitas Sebelas Maret)

Rohmat Indra Borman ( Universitas Teknokrat Indonesia )

Ferry Wongso, S.KOm., M.Kom ( STMIK Darma Pala Riau)

Ferly Ardhy, S.Kom., M.Ti ( Universitas Aisyah Pringsewu )

Firmansyah, S.E., M.Si (STMIK Darma Pala Riau)
Amarudin (Universitas Teknokrat Indonesia)

Didi Susianto, S.T., M.Kom (AMIK Dian Cipta Cendika Bandar Lampung)

Alhibarsyah, St., M.Kom (STMIK Tunas

Bangsa Bandar Lampung)

Kemal Farouq Mauladi, S.Kom .M.Kom (Universitas Islam Lamongan)

Rima Mawarni, M.Kom ( STMIK Dian Cipta Cendikia Kotabumi)

Wira Jaya Hartono, S.Pd., M.Pd ( STMIK Darma Pala Riau)

Penerbit : STMIK Dian Cipta Cendikia Kotabumi Bekerja Sama Dengan LPPM STMIK Dian Cipta Cendikia Kotabumi.

\section{Alamat Redaksi/Penerbit:}

Jl. Negara No. 3 Candimas Kotabumi Lampung Utara

No Telpon/Fax 072423003

Email : 1ppm-stmik@dcc.ac.id 


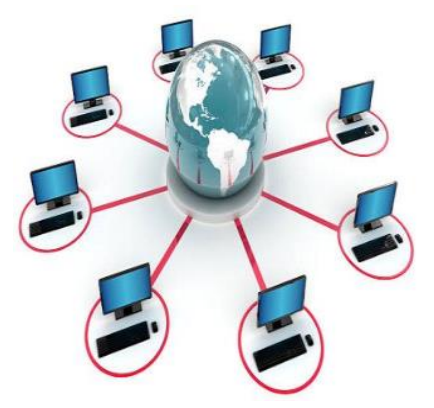

\section{JURNAL INFORMASI DAN KOMPUTER VOL. 9 NO. 2 THN. 2021}

\section{DAFTAR ISI}

Halaman

Sistem Informasi Akuntansi Persedian Barang Berbasis Web Pada Lembaga

Permasyarakatan Kelas II A Banceuy Bandung : "Kelompok Tani Desa Banjar Kertarahayu" Teuku Rian Hardiyansyah, Fatia Salsa Azzahra (Politeknik Piksi Ganesha Bandung ${ }^{1,2}$ ).

Penerapan Finite State Automata Pada Vending Machine Penjual Obat Non Resep

Dokter Dan Keperluan Medis

Eko Supriyanto $^{1}$, Angga Ardiansyah ${ }^{2}$, Frieyadie $^{3}$, Sri Rahayu ${ }^{4}$, Windu Gata ${ }^{5}$

(Universitas Nusa Mandiri ${ }^{12}$ )

Sistem Pendukung Keputusan Untuk Menentukan Kelayakan Pengajuan Sertifikasi Guru Dengan Metode Simple Additive Weighting (Studi Kasus : Ma Al Muhajirin Janti Jogoroto Jombang)

Budiman, umam baharudin, winarti

(Universitas Darul 'Ulum Jombang)

Perancangan Infrastruktur Domain Name Server Lokal Menggunakan Ubuntu Server 16.04

Pada PT. Xyz

Zaenal Mutaqin Subekti, Hendra Setiawan, Satria, Widia Murni Wijaya,

Aliy Hafiz, Warsudi

(STMIK Bani Saleh, Universitas Negeri Yogyakarta, AMIK Dian Cipta Cendikia,

STMIK MIC CIkarang)

Perancangan Sistem Informasi Idea Proposal (Ip) Berbasis Web Pada Pt. Paxel Algorita Unggul

Julian Murhan Sahputra, Indah Purnamasari

(Universitas Nusa Mandiri ${ }^{12}$ )

Sistem Pendukung Keputusan Untuk Menentukan Ekstrakurikuler Atletik

Berdasarkan Bakat Siswa Menggunakan Metode Profile Matching

Agnes Basuki, Petrus Sokibi, Tiara Eka Putri

(Universitas Catur Insan Cendekia)

Penerapan Algoritma K-Means Untuk Pengelompokan Usia Calon Penerima Vaksin

Di Kab. Ngawi

Irna Yuniarfi, Saifulloh

(Universitas PGRI Madiun ${ }^{12}$ )

System Penilaian Seleksi Calon Karyawan Baru Menggunakan Metode Simple Additive Weighting (SAW) Di PT.TNA

Anik Sri Wahyuningsih, Yudhi Firmansyah

(Universitas Panca Sakti Bekasi ) 
Perancangan Sistem Informasi Pembayaran SPP Menggunakan Framework Laravel Ichwan Habib Moudi

(Universitas Panca Sakti Bekasi)

Implementasi Algoritma K-Means Dan Algoritma Apriori Optimasi Kinerja Ecu

(Study Kasus Mobil Avanza Dan Xenia)

Sigit Mintoro' Asep Afandi

(STMIK Dian Cipta Cendikia Kotabumi)

Sistem Pakar Penyakit Buah Kakao Untuk Peningkatan Hasil Panen Kakao Menggunakan

Metode Case Base Reasoning (CBR) Berbasis Web Mobile

Aliy hafiz, Verawati

(AMIK Dian Cipta Cendikia,Bandar Lampung)

Penerapan Metode Rapid Application Develomment (RAD) Dalam Pengembangan

Sistem Pemesanan Menu Berbasis Android

Aris Baihaqi, Tumini

(Fakultas Sains dan Teknologi ${ }^{1,2}$ )

Rancang Bangun Sistem Informasi Geografis Pariwisata Di Lampung Timur

Sukatmi, Rexa Alfa Rizi

(AMIK DCC Bandar Lampung ${ }^{12}$ )

Implementasi Psak No. 45 Pada Proses Penyusunan Laporan Keuangan Menggunakan

M.S. Excel Dan Aplikasi Accurate Accouting Pada STMIK Bani Saleh

Marhakim, Willy Adam

(STMIK Bani Saleh ${ }^{12}$ )

Sistem Prediksi Harga KOPI LAMBAR ( Lampung Barat) Dengan Metode

Backpropagation, dan Double Exponential ( Studi Kasus BUMDES )

Supriyanto, Dwi marisa Efendi,Rhomadhon

(STMIK Dian Cipta cendikia Kotabumi ${ }^{1-}$ )

Sistem Informasi Pemasaran Produk Umkm Berbasis Web Pada Kecamatan Bumi

Nabung Lampung Tengah

Yuli Syafitri, Agus Prasetyo, Reni Astika

(AMIK Dian Cipta Cendikia Bandar Lampung)

Rancang Bangun Aplikasi Pembelajaran Aksara Lampung Berbasis Android

Ferly Ardhy, Hendra Syahrobi

(Universitas Aisyah Pringewu ${ }^{1,}$ STMIK Dian Cipta Cendikia ${ }^{2}$ )

Sistem Pakar Diagnosa Penyakit Kulit Pada Balita Menggunakan Metode Naïve

Bayes Dan Forward Chaining Studi Kasus Puskesmas Cempaka Sungkai Selatan

Sidik Rahmatullah, Rima Mawarni

(STMIK Dian Cipta Cendikia Kotabumi ${ }^{12}$ )

Rekayasa Perangkat Lunak Perhitungan Harga Pokok Produksi Metode

Full Costing Pada Umkm Mitra Cake Di Bandar Lampung

Pitrawati, Arif Sanjaya

(AMIK Dian Cipta Cendikia, Bandar Lampung) 
Rancang Bangun Sistem Ujian Online Menggunakan Algoritma Cosine Similarity

Berbasis Web

Haryono, Zaenal Mutaqin Subekti, Widiyawati, Hidayatullah

(STMIK Bani Saleh ${ }^{1234}$ )

Model Aplikasi Helpdesk Ticketing System Berbasis Web Menggunakan Metode Rad

Indra Permana

Pattern Recognition Tulisan Tangan Huruf Hijaiyah Menggunakan Metode

Convolutional Neural Network (CNN)

Mufassiril Abror, Nopiyanto

(Universitas Panca Sakti Bekasi ${ }^{12}$ )

Aplikasi Sistem Informasi Keuangan Berbasis Android Di Perumahan Taman

Karang Bahagia

Melda Ayulestari

(Universitas Panca Sakti Bekasi)

Audit Pelayanan Sistem Rujukan Online Puskesmas Menggunakan Framework COBIT 5.0

Nurmayanti, Merri Parida, Ngajiyanto, Ina Anzalna

(STMIK Dian Cipta Cendikia Kotabumi ${ }^{1234}$ )

Perancangan Sistem Informasi Pengolahan Data Nilai Siswa Berbasis Web

Erin Ermawati, Anik Sri Wahyuningsih

(Fakultas Sain dan Teknologi, Universitas Panca Sakti Bekasi ${ }^{12}$ )

Pengembangan Sistem Pelaporan Data Hasil Inspeksi Barang Berbasis Web

Siska Putriani

(Universitas Pancasakti Bekasi)

Penerapan Extreme Programming Dalam Perancangan Aplikasi Web Food Market

Tumini, Hilman Septiana

(Fakultas Sains dan Teknologi Universitas Panca Sakti Bekasi ${ }^{1,2}$ )

Sistem Pencarian Barang Berbasis Website Menggunakan Php Dan Mysql

Studi Kasus PT. Surya Technology Industri Sulaeman

(Universitas Panca Sakti Bekasi)

Implementasi Metode Prototype Pada Sistem Peminjaman Alat Kerja Berbasis Web

Di PT SK Metalindo

Ali Mulyanto, Arjun Gunawan

(Univeritas Panca Sakti Bekasi)

Aplikasi Tata Cara Wudhu Menggunakan Teknologi Augmented Reality

Sebagai Media Pembelajaran Di TK Al Fatih

Ahmad Yakub, Idarul Fadli

(Universitas Panca Sakti Bekasi ${ }^{12}$ )

Sistem Pakar Diagnosa Penyakit Ayam Petelur Menggunakan Metode Certainty Factor

Berbasis Web Mochammad

Taufiq Hidayat, Ali Mulyanto

(Universitas Panca Sakti Bekasi ${ }^{12}$ ) 
Penerapan Metode Prototyping Dalam Perhitungan Hasil Produksi Menggunakan

Arduino Uno R3 Dan Php Di PT. Indonesia Epson Industry

Amandha Aulia, Ajar Rohmanu

(Universitas Panca Sakti Bekasi ${ }^{12}$ )

System Pendukung Keputusan Penentuan Guru Teladan Dengan Metode Profile Matching

Hasbulloh, Agmawarnida

(Universitas Panca Sakti Bekasi ${ }^{1,2}$ )

Implementasi Waterfall Method Pada Aplikasi Buku Induk Siswa Berbasis Web

Idam Holid, Yogie Krisnayadi

(Universitas Panca Sakti ${ }^{12}$ )

Pengembangan Text To Speech Media Pembelajaran Untuk Pengenalan

Anggota Tubuh Manusia Kelas V Sekolah Dasar

Juwanda Saputra, Ali Mulianto

(Teknik Infomratika Fakulutas Sains dan Teknologi ${ }^{12}$ )

Perancangan Sistem Peminjaman Barang Berupa Aset Tetap Berbasis Web

Pada Lembaga Permasyarakatan Kelas II A Banceuy Bandung

Guntur Salasa Priambodo, Perwito, Candra Mecca Sufyana

(Politeknik Piksi Ganesha Bandung ${ }^{1,2,3}$ )

Metode Pemilihan Karyawan Terbaik Sebagai Penentu Goodwill Perguruan Tinggi

Dengan Menggunakan Metode Topsis (Studi Kasus Perguruan Tinggi Di Lampung Utara)

Dwi Sartika, Pakarti Riswanto

(STMIK Dian Cipta Cendikia Kotabumi)

Sistem Pendukung Keputusan Pemilihan Merek Smartphone Menggunakan

Metode Analytical Hierarchy Process (AHP)

Ade Kiki Fatmawati, Muhammad Sultan Raflie, Norma Yunita

(Universitas Nusa Mandiri ${ }^{123}$ )

Pattern Recognition Aksara Lampung Menggunakan Algoritma Neural Network

Metode Analytical Hierarchy Process (AHP)

Nopiyanto, Rahmadi

(Universitas Panca Sakti Bekasi) 


\title{
SISTEM PAKAR PENYAKIT BUAH KAKAO UNTUK PENINGKATAN HASIL PANEN KAKAO MENGGUNAKAN METODE CASE BASE REASONING (CBR) BERBASIS WEB MOBILE
}

\author{
Aliy hafiz ${ }^{1}$, Verawati ${ }^{2}$ \\ AMIK Dian Cipta Cendikia,Bandar Lampung \\ Email:hafiz@dcc.ac.id, verawati@dcc.ac.id
}

\begin{abstract}
ABSTRAK
Kakao merupakan salah satu komoditas pertanian yang menjadi penyumbang perekonomian yang menjadi andalan bagi negara Indonesia. Hal ini karena Indonesia merupakan penghasil biji kakao (kakao beans) terbesar ketiga di dunia dengan pangsa produksi sebesar 15,68\%. Salah satu faktor yang menyebabkan rendahnya kualitas cokelat di Indonesia adalah karena perkebunan kakao di Indonesia selalu diancam oleh hama dan penyakit tumbuhan. Serangga merupakan jenis hama yang jumlahnya terbesar untuk tanaman kakao di Indonesia lebih dari 130 spesies. Kurangnya informasi yang diketahui oleh pihak perkebunan kakao tentang jenis penyakit yang menyerang tanaman cokelat, menyebabkan banyaknya tanaman cokelat yang tidak tertangani dengan benar. Hal ini mengakibatkan banyak tanaman cokelat yang seharusnya bisa diselamatkan menjadi mati dan kualitas cokelat tersebut menurun. Berdasarkan uraian di atas, pihak perkebunan cokelat membutuhkan sebuah sistem pakar yang dapat memberikan informasi mengenai penyakit yang menyerang tanaman kakao dan memberikan solusi untuk menangani penyakit tersebut. Sistem pakar merupakan paket perangkat lunak atau paket program komputer yang ditunjuk sebagai penyedia nasehat dan sarana bantuan dalam memecahkan masalah dibidang spesialisasi tertentu seperti sains, perekayasaan, matematika, kedokteran, pendidikan dan sebagainya. Tujuan praktis dari sistem pakar ini adalah membuat komputer semakin berguna bagi manusia. Adapun metode yang digunakan dalam membangun sistem pakar ini adalah metode case base reasoning (CBR). Kemudian metode pengembangan sistem yang digunakan adalah extreme programmingpenelitian yang dihasilkan yaitu aplikasi sistem pakar berbasis web mobile yang membantu petani dalam memecahkan masalah dalam pertanian kakao.
\end{abstract}

Kata kunci : Sistem Pakar, Kakao,CBR

\section{ABSTRACTS}

Cocoa is one of the agricultural commodities that contribute to the economy which is a mainstay for the state of Indonesia. This is because Indonesia is the third largest producer of cocoa beans (kakao beans) in the world with a production share of $15.68 \%$. One of the factors that causes the low quality of chocolate in Indonesia is that cocoa plantations in Indonesia are always threatened by pests and plant diseases. Insects are the most common type of pest for cocoa plants in Indonesia, with more than 130 species. Lack of information that is known by the cocoa plantations about the types of diseases that attack cocoa plants, causing many cocoa plants that are not handled properly. This resulted in many cocoa plants that could have been saved to die and the quality of the chocolate decreased. Based on the description above, cocoa plantations need an expert system that can provide information about diseases that attack cocoa plants and provide solutions to deal with these diseases. The method used in building this expert system is the case base reasoning (CBR) method. Then the system development method used is extreme programming. The resulting research is a mobile web-based expert system application that helps farmers solve problems in cocoa farming.

Keywords: Expert System, kakao,CBR

\section{PENDAHULUAN}

Kakao merupakan salah satu komoditas pertanian yang menjadi penyumbang perekonomian yang menjadi andalan bagi negara Indonesia. Hal ini karena Indonesia merupakan penghasil biji kakao (kakao beans) terbesar ketiga di dunia dengan pangsa produksi sebesar $15,68 \%$. Salah satu faktor yang menyebabkan rendahnya kualitas cokelat di 
Indonesia adalah karena perkebunan kakao di Indonesia selalu diancam oleh hama dan penyakit tumbuhan [1]. Serangga merupakan jenis hama yang jumlahnya terbesar untuk tanaman kakao di Indonesia lebih dari 130 spesies. Kurangnya informasi yang diketahui oleh pihak perkebunan kakao tentang jenis penyakit yang menyerang tanaman cokelat, menyebabkan banyaknya tanaman cokelat yang tidak tertangani dengan benar[2]. Hal ini mengakibatkan banyak tanaman cokelat yang seharusnya bisa diselamatkan menjadi mati dan kualitas cokelat tersebut menurun. Sistem pakar merupakan paket perangkat lunak atau paket program komputer yang ditunjuk sebagai penyedia nasehat dan sarana bantuan dalam memecahkan masalah.

Aplikasi sistem pakar ini bertujuan membantu pihak perkebunan cokelat untuk mengetahui jenis penyakit yang sedang menyerang tanaman cokelat berdasarkan pada gejala-gejala penyakit yang terlihat dan juga dengan adanya aplikasi sistem pakar ini, dapat menghasilkan solusi untuk menangani tanaman cokelat yang terserang penyakit, sehingga banyak tanaman cokelat yang terselamatkan dan hal ini dapat meningkatkan produksi dan juga kualitas[3].

\section{METODE PENELITIAN}

\section{a. Jenis Penelitian}

Jenis penelitian yang digunakan pada penelitian ini adalah model eksperimental. Model eksperimental yang merupakan model penelitian yang bersifat uji coba, memanipulasi, dan mempengaruhi hal-hal yang terkait dengan seluruh variabel atau atribut dari penelitian ini. Penelitian eksperimental bertujuan untuk membangun Sistem Pakar Penyakit Buah Kakao Untuk Peningkatan Hasil Panen Kakao Menggunakan Metode Case Base Reasoning (CBR) Berbasis Web Mobile.

\section{b. Alur Penelitian}

Berikut ini adalah alur penelitian yang diajukan;

Tahap 1:

Kajian Pustaka

Identifikasi Masalah

Pengumpulan Data
Tahap 2:

Analisis Data

Analisa CBR

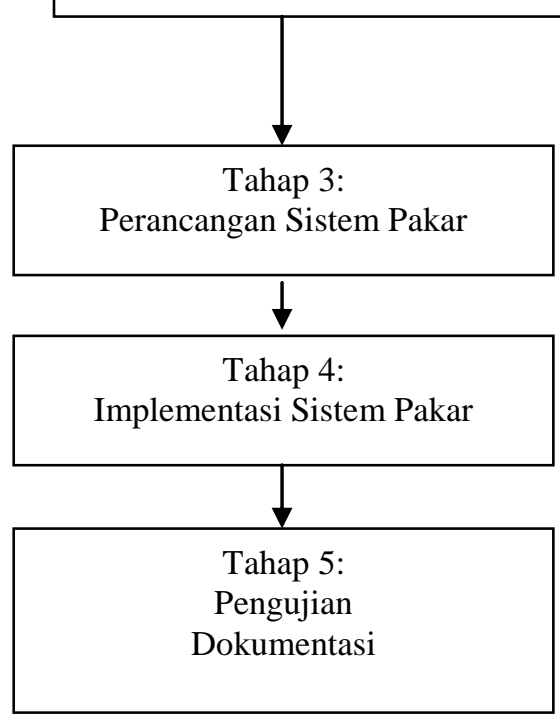

Gambar 1. Kerangka penelitian Sistem Pakar

Kerangka penelitian yang terdiri dari tahapantahapan diatas dapat dijelaskan seperti berikut ini :

\section{Tahap 1:}

Pada tahap 1 ini yang dilakukan yaitu kajian pustaka, identifikasi masalah, dan pengumpulan data

\section{Tahap 2:}

Pada tahap 2 ini yang dilakukan yaitu analisis data dan analisa menggunakan metode CBR.

\section{Tahap 3:}

Pada tahap 3 ini yang dilakukan yaitu merancang dari Sistem Pakar yang akan dibangun.

\section{Tahap 4:}

Pada tahap 4 ini yang dilakukan yaitu Implementasi Sistem Pakar yang telah dirancang.

Tahap 5: 
Pada tahap 5 ini yang dilakukan yaitu pengujian sistem yang telah dibangun kemudian melakukan dokumentasi.

\section{c. Metode Pengumpulan Data}

Adapun cara pengumpulan data dalam penelitian ini adalah sebagai berikut:

\section{Observasi}

Observasi dilakukan dengan cara melihat dan mengamati secara langsung cara bertani kakao.

2. Studi Pustaka

Studi Pustaka dilakukan dengan mengutip serta membuat catatan yang bersumber dari bahan-bahan pustaka yang mendukung dan berkaitan dengan penelitian ini.

3. Wawancara

Wawancara yaitu melakukan tanya jawab langsung kepada ahli pertanian dan petani yang terlibat dengan masalah yang diteliti.

\section{d. Metode pengembangan sistem}

Metode pengembangan sistem yang digunakan dalam penelitian ini adalah extreme programing $(x p)$. Metode XP ini memiliki beberapa tahapan dalam menyelesaikan sistem atau aplikasi yaitu dengan planning atau perencanaan, desain, coding, dan yang terakhir testing/uji [4].

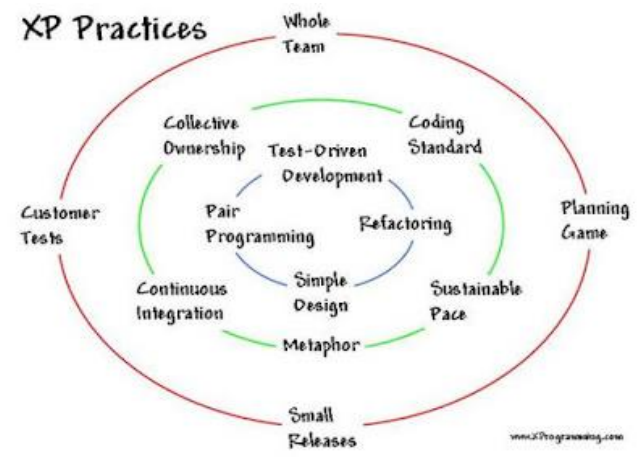

Gambar 1. Tahapan model Extreme Programing

Pengembangan sistem model extreme programing terdapat beberapa tahapan yaitu: 1) planning (merencanakan sistem yang akan dibangun) 2) desain (mendesain sistem yang akan dibangun) 3) coding (implementasi kedalam bentuk koding) 4) testing (melakukan testing atau uji coba dari aplikasi/sistem yang telah dibangun).
UML (Unified Modelling Language) adalah bahasa yang banyak digunakan dalam dunia industri yang banyak digunakan untuk menjelaskan kebutuhan, membuat analisis. Selain itu digunakan untuk desain dan menggambarkan arsitektur dalam pemrograman berorientasi objek (PBO)[5].

\section{e. Case base reasoning (CBR)}

CBR (Case Base Reasoning) yaitu suatu pendekatan untuk menyelesaikan suatu permasalahan (problem solving) berdasarkan solusi dari permasalahan sebelumnya. didalam CBR terdapat 4 tahapan proses yang dibentuk dalam mengambil suatu kasus sehingga membentuk satu pemecahan masalah yang berdasarkan pengalaman yang sudah pernah ada. Tahapan tersebut meliputi Retrieve (penelusuran) kembali dengan kasus yang sama atau yang paling mirip dengan kasus baru, Reuse (menggunakan kembali) informasi dan pengetahuan dari penympanan kasus untuk memecahkan masalah kasus baru, Revise (memperbaiki) kasus lama, dan Retain (mempertahankan) atau menyimpan pengalaman kedalam basis kasus[6].

CBR menggunakan pendekatan kecerdasan buatan (Artificial Intelligent) yang menitikberatkan pemecahan masalah dengan didasarkan pada knowledge dari kasus-kasus sebelumnya. Apabila ada kasus baru maka akan disimpan pada basis pengetahuan sehingga sistem akan melakukan learning dan knowledge yang dimiliki oleh sistem akan bertambah. Proses dalam CBR dapat menggunakan berbagai teknik, diantaranya adalah algoritma nearest neighbor. Nearest Neighbor adalah menghitung tingkat kemiripan (jarak) suatu kasus terhadap kasus baru berdasarkan beberapa atribut yang di definisikan berdasar pembobotan tertentu dan kemudian tingkat kemiripan (jarak) dari keseluruhan atribut akan di jumlahkan. Nearest Neighbor di definisikan berdasarkan persamaan sebagai berikut :

$$
\text { Similarity }(S, T)=\sum_{t=1}^{n} f\left(T_{t}, S_{t}\right) x w t
$$

$\mathrm{T}:$ Kasus target / baru

$\mathrm{S}:$ Kasus / lama / pembanding

$\mathrm{n}$ : Jumlah atribut dalam setiap kasus

$\mathrm{i}$ : Atribut individu dari 1 sampai $\mathrm{n}$

$\mathrm{f}$ : Fungsi kemiripan untuk atribut I dalam kasus $\mathrm{T}$ dan $\mathrm{S}$ 
w : Bobot atribut i

Kedekatan kasus ditentukan dengan nilai 0 sampai dengan 1, karena perhitungan Nearest Neighbor menggunakan perhitungan yang real yaitu antara nilai $(0,1)$. Nilai 0 artinya Kedua kasus mutlak tidak mirip dan nilai 1 kasus mutlak mirip[7].

Perhitungan Similarity bertujuan untuk memilih kasus yang relevan atau cocok, dengan asumsi dasar yang digunakan adalah suatu permasalahan yang mirip akan memiliki solusi yang mirip juga. Maka dari perhitungan Similarity dengan batas minimum kemiripan kasus (Treshold) yang telah ditentukan oleh pakar. Dalam Mencari kasus yang memiliki kemiripan dengan kasus baru, setiap kasus baru akan disamakan dengan semua kasus yang ada pada basis kasus dengan bagian faktor-faktor diatas,

Faktor Kemiripan $(\boldsymbol{F K})=(\mathrm{WA} 1 *$ FA1 $)+$ (WA2 * FA2)

$+(\mathrm{WA} 3 * \mathrm{FA} 3)+(\mathrm{WA} 4 * \mathrm{FA} 4)$

Penjelasan :

1. Fx adalah faktor nilai tiap atribut.

2. W adalah bobot tiap atribut.

3. A1 - A4 adalah faktor

\section{HASIL DAN PEMBAHASAN}

\subsection{Perancangan Sistem}

Berikut ini adalah use case dari sistem pakar penyakit kakao berbasis web mobile.

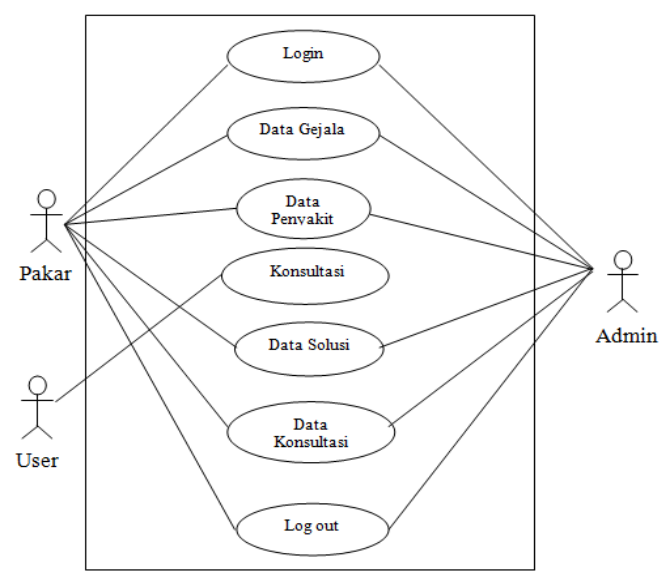

Gambar 3. Use Case Sistem

\subsection{Desain Dan Perancangan Basis Data}

Rancangan Database pada sistem ini digambarkan pada tabel-tabel dibawah ini. Nama Tabel : Cbr_Kasus

Tabel 1. Struktur Tabel Cbr Kasus

\begin{tabular}{|c|l|l|l|}
\hline No & \multicolumn{1}{|c|}{ Field } & \multicolumn{1}{|c|}{ Type } & Width \\
\hline 1 & Id_Kasus & Int & 11 \\
\hline 2 & Nama & Varchar & 50 \\
\hline 3 & Id_Kerusakan & Int & 11 \\
\hline 4 & Tanggal & Date & \\
\hline 5 & Status & Int & 1 \\
\hline
\end{tabular}

Nama Tabel : Cbr_Penyakit

Primary key : Id_Penyakit

Tabel 2. Struktur Tabel Cbr_ Penyakit

\begin{tabular}{|c|l|l|l|}
\hline No & \multicolumn{1}{|c|}{ Field } & \multicolumn{1}{c|}{ Type } & Width \\
\hline 1 & Id_Penyakit & Int & 11 \\
\hline 2 & Nama_Penyakit & Varchar & 50 \\
\hline 3 & Kode_Penyakit & Varchar & 5 \\
\hline 4 & Solusi & Text & \\
\hline
\end{tabular}

Nama Tabel : Cbr_Solusi

Primary key : Id_Solusi

Tabel 3. Struktur Tabel Cbr_Solusi

\begin{tabular}{|c|l|l|l|}
\hline No & \multicolumn{1}{|c|}{ Field } & \multicolumn{1}{|c|}{ Type } & Width \\
\hline 1 & Id_Solusi & Int & 11 \\
\hline 2 & Kode_Solusi & Varchar & 5 \\
\hline 3 & Nama_Solusi & Varchar & 100 \\
\hline 4 & Keterangan & Text & \\
\hline
\end{tabular}

\subsection{Rancangan Muka Aplikasi}

Berikut ini adalah rancangan tampilan muka login dari sistem pakar penyakit kakao berbasis web mobile.

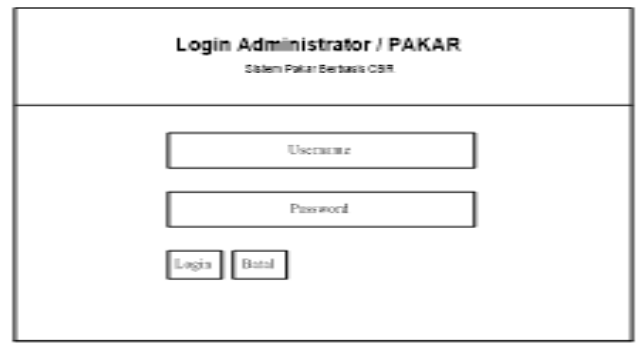

Gambar 4. Rancangan Muka Login 


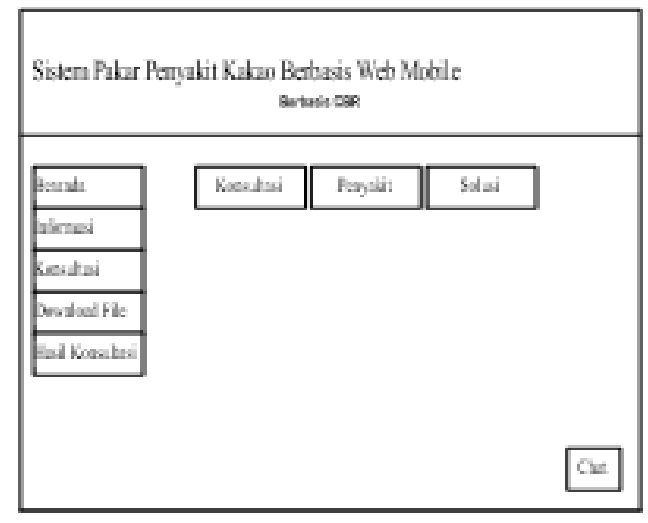

Gambar 5. Rancangan Muka Utama Aplikasi

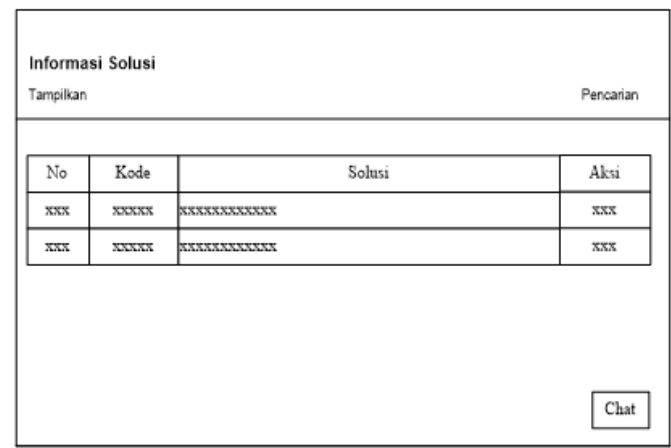

Gambar 6. Rancangan Muka Solusi Aplikasi

\subsection{Hasil Aplikasi}

Berikut ini adalah halaman utama aplikasi yang berisi menu seperti beranda, informasi, konsultasi, download file dan hasil konsultasi.

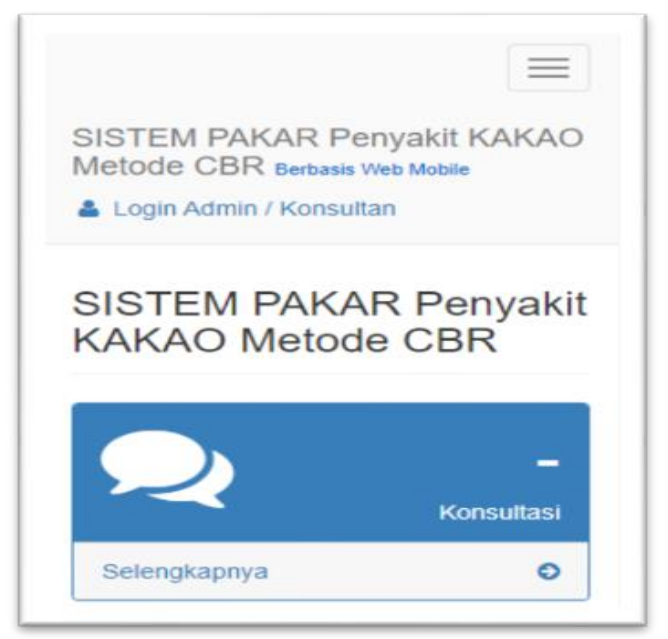

Gambar 7. Halaman utama aplikasi sistem pakar
Berikut ini adalah halaman konsultasi sistem pakar dimana user terlebih dahulu memasukkan data diri kemudian memasukkan informasi mengenai gejala yang ada pada tanaman kakao/cokelatnya.

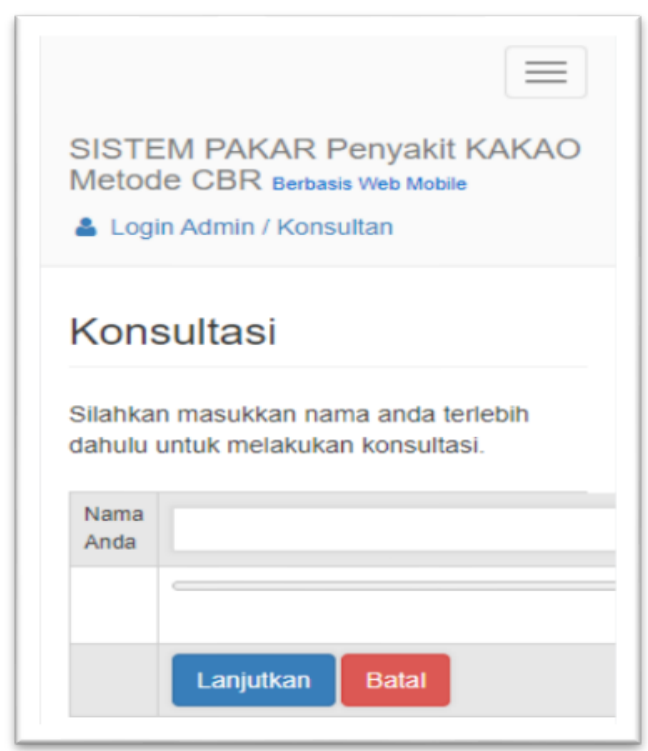

Gambar 8. Halaman konsultasi sistem pakar

Berikut ini adalah halaman login admin dari sistem pakar yang berguna untuk mengelola sistem pakar dimana admin bisa menambahkan berbagai informasi tentang sistem pakar seperti gejala dan penyakit dari tanaman kakao.
Login Administrator
SISTEM PAKAR Penyakit KAKAO
Metode CBR
Username
Password
Login
Batal
Gambar 9. Halaman login admin sistem pakar
Berikut ini adalah halaman download file dari sistem pakar yang berguna untuk mengunduh hasil konsultasi dengan sistem pakar. 


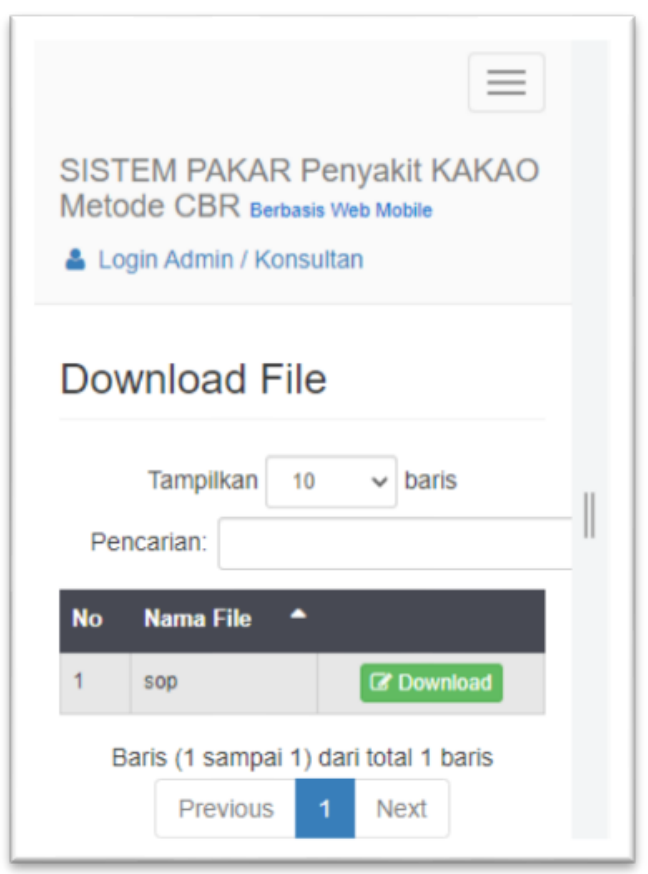

Gambar 10. Halaman download sistem pakar

\section{KESIMPULAN}

Adapun kesimpulan dari penelitian ini adalah metode case base reasoning dapet digunakan dalam penyelesaian masalah sebagai sistem pakar. Hendaknya dilakukan pengujian whitebox dan bisa dibandingkan dengan metode lain dalam pengembangan sistem pakarnya.

\section{DAFTAR PUSTAKA}

[1] Lestari, P. (2018). Intensitas serangan hama penggerek batang kakao di perkebunan rakyat Cipadang, Gedongtataan, Pesawaran. Jurnal Agro Industri Perkebunan, 6(1), 18.

[2] Armaniar, A., Saleh, A., \& Wibowo, F. (2019). Penggunaan Semut Hitam dan Bokashi dalam Peningkatan Resistensi dan Produksi Tanaman Kakao. AGRIUM: Jurnal Ilmu Pertanian, 22(2), 111-115.

[3] Septiana, S., Dirmawati, S. R., \& Evizal, R. (2020). Aplikasi Kitosan Untuk Pengendalian Penyakit Busuk Buah Kakao (Phytophthora megakarya
L.). Jurnal Agrotropika, 19(1), 2226.

[4] Warman, I., \& Handayani, W. (2017). CaseBased Reasoning (Cbr) Pada Sistem Pakar Identifikasi Hama Dan Penyakit Tanaman Singkong Dalam Usaha Meningkatkan Produktivitas Tanaman. Jurnal Teknoif ITP, 5(1), 41-47.

[5] Nasution, S. W., Hasibuan, N. A., \& Ramadhani, P. (2017). Sistem Pakar Diagnosa Anoreksia Nervosa Menerapkan Metode Case Based Reasoning. KOMIK (Konferensi Nasional Teknologi Informasi dan Komputer), 1(1).

[6] Gupita, G., Harijanto, B., \& Ariyanto, Y. (2017). Pengembangan Sistem Pakar Pendeteksi Penyakit Pada Kucing Dengan Metode Case Based Reasoning Dan Certainty Factor Berbasis Android. Jurnal Informatika Polinema, 3(2), 8-8.

[7] Ma'mur, M., Lia, L., \& Hafiz, A. (2019). Metode Extreme Programming Dalam Membangun Aplikasi KosKosan Di Kota Bandar Lampung Berbasis Web. Jurnal Cendikia, 18(1), 377-383. 